\title{
Kekerasan dalam Media Massa dan Makna Pers Pancasila
}

\author{
Soemadi M Wonohito
}

The following article tries to explain the violence that publishes either in printed media or in electronic media. Mass media is often criticized when publish or display violence news although fact-based. The violence of media implies trauma. Trauma is not only individual psychological aspect, but also social structure, political authority, and the cultural values. In this sense trauma can not only handled and soilved by psychologists. but also should need anthropologists, sociologists and other fields of social scientists participation to identify the factors the above mentioned.

Kata kunci: media, kekerasan, trauma, terapi, dan pers.

D alam sebuah rubrik pikiran pembaca di SKH Kedaulatan Rakyat, ada seoráng ibu menuliskan keluhannya, andai korankoran dan televisi sekarang diperas, tentu akan keluar darah. Keluhan yang meggelitik nurani, setelah ibu tersebut mengamati realitas betapa berita kekerasan mendominasi pemberitaan media massa saat ini. Banyak media cetak dan elektronik seolah bersaing menyajikannya berita kriminal secara vulgar dan sadis. Hari-hari pasti ada wajah babak belur, sosok mayat dalam keadaan mengenaskan, kejahatan seksual pun menjadi isian media massa cetak dan elektronik. Halaman koran dan televisi menjadi berdarah-darah setiap hari.

Ditambah.lagi korupsi yang merajalela di negeri ini, baik dilakukan oleh legislatif, eksekutif, para aparat penegak hukum, semakin memperburuk wajah negeri kita.

Celakanya, ada yang menganggap kekerasan dan korupsi diterjemahkan karena bangsa ini memiliki akar büdaya itu. Kelakukan buruk tersebut peninggalan ketika negeri ini dijajah VOC dan Jepang.

Tetapi benarkah demikian? Apakah pengambinghitaman àkar budaya itu bukan mencari alasan pembenaran saja. Selain itu, apakah kekerasan itu juga pengaruh dari penjajahan Jepang atau VOC. Bukankah Singapura, yang dijajah oleh Jepang dan sebelumnya oleh Inggris, tidak seperti Indonesia.

Media massa memang sering disalahkan ketika memuat atau menayangkan berita-kekerasan.-Padahal yang terjadi, sebenarnya media memuat berdasarkan fakta kekerasan muncul di ruang publik, sehingga bila kekerasan itu terungkap di media massa maka itulah sebenarnya ceminan peristiwa yang sedang terjadi di negeri ini.

Memang kalau dibandingkankan dengan era Orde Baru, keterbukan media massa tidak seperti sekarang. Ketika itu, fakta kekerasan bisa lebih:"dikontrol". 
Sehingga bisa diatur, mana yang akan lebih "dikeraskan" dan mana yang tidak, atau malah sama sekali tidak boleh dimuat. Pemerintah dengan seenaknya akan menutup media yang tak bisa 'dikontrol', karena sistem perundangan memang memungkinkan. Saya masih ingat, di era orde baru pernah ada pesawat latih milik TNI $\mathrm{AU}$ jatuh di Kaliurang. Masyarakat sekitar sudah tahu kalau ada pesawat jatuh, tetapi Skh KR dilarang memuat oleh aparat. Alasannya, untuk menjaga stabilitas kèamanan dan rahasia negara. Ini kan aneh. Dan masih banyak lagi larangan,jika pemberitaan menyangkut pemerintah.

Tetapi pasca reformasi semua menjadi bebas: "Sistem perundangan sekarang memungkinkan media bisa muncul kapan dan dimanapun. Media massa tidak bisa dibredel oleh siapapun. Dari sisi pertumbuhan media massa dan kebebasan Pers memang menyenangkan. Namun dampak lainnya menyebabkan persaingan antar media menjadi tidak sehat. Banyak media massa yang berusaha menjadi kanibal, memakan sesama media dengan menghalalkan segala cara. Alhasil terjadi periombaan menampilkan kekerasan secara vulgar sebagai sarana mencari nafkah. Segmen berita kriminal dan seksual menjadi andalan mencari uang tanpa - mengindahkan dampak kejiwaan bagi masyarakat dan terutama kanak-kanak. Media massa menjadi.ajang kampanye negatif kekerasan.

Pendiri Surat Kabar Harian Kedaulatan Rakyat, M Wonohito mengatakan : Yang bisa menerangi dunia adalah matahari yang terbit dari timur dan pers yang bebas dan bertanggungjawab. Dalam pemahaman saya, konsep yang kemudian diberikan oleh $M$ Wonohito adalah Pers Pancasila sangat pas sebagai resep penyelesaiannya pada kondisi semacam ini. Pedoman ini yang saya gunakan untuk menjalankan Skh Kedaulatan Rakyat hingga sekarang menapak usia ke 60 tahun lebih. Memang tidak mudah, karena Pancasila kemudian tidak populer lantaran diselewengkan maknanya oleh rezim orde baru. Pancasila sekadar simbol dan menjadi proyek penataran.

Kebebasan Pers sebenarnya memang milik publik. Dengan kebebasan pers, semua bisa menjadi terang dan gamblang. Pada era reformasi, Pers sudah bebas melakukan apa saja. Tetapi sebagian pers lupa, bahwa Pers yang kebablasan melanggar apa saja, bisa menjadi anarkis bagi yang dilanggar. Kalangan Pers memang sudah menyiapkan rambu-rambunya antara lain dengan Kode Etik Jurnalistik. Tetapi, seberapakah yang mentaati? Saya ragu, apakah semua pengelola media massa alihalih mentaati, membacapun mungkin belum pemah.

Karena itu dalam pandangan saya, hal tersebut tak mungkin terjadi andaikan kita melaksanakan 'ajaran' yang terkandung dalam sistem Pers Pancasila. Yakni pers bebas yang bertanggungjawab terhadap nurani masyarakat, negara dan hukum dan tetap mengedepankan tenggang rasa (tepo slira).

Pers Pancasila menyeimbangkan antara kepentingan individu dengan masyarakat. Juga menyeimbangkan antara kesejahteraan materiil dengan kesejahteraan spiritual. Filosofi Jawa 'ngono ya ngono ning aja ngono' (begitu yang begitu, tetapi jangan begitu) sangat sesuai. Berdasarkan pengalaman empirik saya memimpin Skh KR, semua wartawan KR harus melaksanakannya filosofi tersebut. Mereka paham, bahwa jadi wartawan tidak boleh sok. Mentang-mentang wartawan menjadi besar kepala, beritanya menista, memfitnah, menuduh tanpa dasar, memuat 
semua kekerasan tanpa memikirkan dampak pemuatan. Memang sesuai dengan tugasnya, Pers harus melakukan kontrol sosial. Mereka selalu melakukan kritik, tetapi jangan mempermalukan yang dikritik.

Ada filosofi Jawa 'aja ngongoti barang lincip' (jangan memperuncing barang yang sudah runcing). Rasa-rasanya, masalah bangsa ini tidak akan pernah selesai jika semua elemen bangsa, termasuk media massa selalu memperuncing masalah. Ini sejalan dengan sistem Pers Pancasila.

\section{Sebab-sebab Terjadinya Kekerasan}

Tidak jarang kita mendengar pendapat bahwa tindak kekerasan terjadi disebabkan oleh kemiskinan. Bahkan sampai ada yang mengatakan bahwa orang miskin memang gampang ngamuk. Memang, bukan sekali dua kali kita mendengar atau membaca bahwa di kawasan kumuh yang penuh penduduk miskin terjadi tindak kekerasan. Ada masalah sedikit, langsung terjadi main pukul, tusuk, dan seterusnya.

Namun, rasanya terlalu berlebihan bila sampai menyebut orang miskin cenderung melakukan kekerasan. Kalau kemudian dikatakan bahwa orang yang pendidikannya rendah gampang menggunakan kekerasan untuk menyelesaikan persoalan atau konfik, mungkin masih bisa diterima, sekalipun masih bisa dibantah pula karena dalam kelompok-kelompok masyarakat tertentu yang miskin dan kurang mengenyam pendidikan formal sekalipun tidak jarang justru terdapat cara-cara yang lebih damai untuk mencari solusi konflik yang terjadi di lingkungan mereka. (Aloysius Gunadi, 2004)

Kekerasan bisa hadir dalam berbagai bentuk. Namun, yang lebih penting dari.tu adalah mengapa kekerasan itu sampai terjadi? Para ahli telah menyebutkan banyak faktor yang potensial menjadi penjelas terjadinya kekerasan. Dan, di antara berbagai faktor itu, tersebutkan pula faktor kebijakan ekonomi, lebih khusus lagi adalah yang menjadi penyebab kemiskinan dan ketimpangan baik antar anggota masyarakat ataupun antardaerah. Ketika kebijakan ekonomi tersebut berada dalam konteks pembangunan yang bias ke targettarget ekonomi, maka pembangunan itu pun bisa menjadi pemicu terjadinya kekerasan.

World Social Summit di Mumbai beberapa waktu lalu pun disebut-sebut meyakini adanya kaitan yang erat sekali antara kemiskinan dan kekerasan. Beberapa studi empiris memang telah memberikan indikasi bahwa ada benarnya kondisi sosial dan ekonomi yang buruk dan terasa tidak adil merupakan salah satu sebab dari terjadinya konflik kekerasan. Lantas, pertumbuhan ekonomi pun dinilai penting agar masyarakat mampu mengelola konflik yang muncul. Pada situasi dimana kesejahteraan relatif memadai dan stabil, kekerasan mungkin lebih minimal. Pendapat seperti ini kerap dikaitkan dengan kenyataan banyak negara-negara miskin, di Afrika khususnya, yang bertahun-tahun tenggelam dalam perang antar süku, sementara hal serupa tidak terjadi di negaranegara kaya.

Kendati demikian, tetap perlu digarisbawahi bahwa tidak sedikit pula yang mengingatkan bahwa hubungan antara faktor ekonomi dan kekerasan itu sebetulnya tidaklah mudah untuk dipastikan. Dengan kata lain ada kompleksitas yang melingkupi hubungan itu. Secara ekstrem, muncul bantahan bahwa bukan kemiskinan yang menjadi penyebab kekerasan, melainkan kekerasan itulah yang menjadi sebab utama berlanjutnya kemiskinan. Kedua pendapat yang berlawanan ini sesungguhnya juga memberikan indikasi bahwa antara 
kemiskinan dan kekerasan dapat saja berlangsung hubungan yang simultan.

Kekerasan merupakan fenomena yang kompleks, dan oleh karena itu tidak bisa dilihat dari kacamata tunggal semata. Dengan tetap mengingat hal ini, kiranya menarik untuk menyimak faktor-faktor ekonomi apa saja yang dapat ikut menjadi penyebab terjadinya kekerasan. Dari beberapa ahli, beberapa faktor ekonomi yang diyakini erat kaitannya dengan kemiskinan adalah sebagai berikut.

Pertama adalah parahnya kesenjangan antara pendapatan dan kesejahteraan antara yang kaya dan miskin. Dalam kenyataannya, memang masih banyak penduduk hidup dalam kemiskinan. Kemiskinan boleh jadi ada yang disebabkan oleh kemalasan. Namun, dalam konteks ini yang dimaksudkan adalah kemiskinan sebagaiakibat perilaku jahat dari kelompok yang kaya. Banyak yang bekerja keras dan bertindak jujur, namun toh tidak juga lepas dari kemiskinan ketika di dalam hubunganhubungan antar pelaku ekonomi tersebut terjadi tindak-tindak eksploitatif. Kekecewaan yang berlarut-larut ini bukan tidak mungkin akhirnya memunculkan keinginan untuk melakukan tindakan balasan dimana kekerasan mungkin menjadi cara yang dipilih. Namun, terdapat catatan di sini, yaitu bahwa yang memilih jalan ini pun sebetulnya hanya sebagian kecil dari mereka yang tertindas. Ada kekhawatiran pula bahwa bagian inilah yang mudah diagitasi dan dibentuk untuk menjadi pelaku kekerasan dan kekacauan oleh pihak-pihak lain yang justru mungkin datang dari kelompok yang makmur dengan menyembunyikan motivasi atau kepentingan mereka yang sesungguhnya.

Faktor lain adalah 'tingginya tingkat pengangguran, khususnya di kalangan muda di daerah perkotaan. Persoalan ini amat terasa ketika situasi ekonomi mengalami kemerosotan. Setiap tahun begitu banyak kaum muda yang masuk ke pasar tenaga kerja. Namun oleh karena terbatasnya lapangan kerja maka banyak yang menjadi pengangguran. Sebagian mungkin ada yang kemudian memilih untuk masuk ke sektor informal, menjadi pekerja mandiri kendati tetap menyimpan keinginan untuk memperoleh pekerjaan yang lebih baik. Kaum muda yang pendidikannya tidak cukup baik, mungkin tidak perlu berpikir lama untuk mengambil keputusan masuk ke sektor informal. Namun, kaum muda yang terdidik mungkin memilih untuk tetap mencoba ke sector formal. Di sinilah mereka tersadar betapa amat kecil peluang mereka untuk bisa mendapatkan pekerjaan. Tentu, hal ini diperparah pula dengan seringnya nepotisme, koneksi, korupsi menjadi penentu pengalokasian pekerjaan dan makin meningkatkan kekecewaan mereka yang telah menyelesaikan pendidikannya, namun tidak punya koneksi atau uang untuk memperoleh pekerjaan. Menumpuknya kekecewaan ini bisa saja kemudian berbuah pada pilihan untuk bergabung dengan kelompok-kelompok yang ektrim dan menggunakan kekerasan sebagai cara untuk meluapkan kekecewaan mereka.

Faktor lain yang juga dapat memperkuat pengaruh hal-hal di atas adalah situasi lingkungan, khususnya di perkotaan, yang kacau berikut tidak memadainya akses pelayanan-pelayanan publik yang penting sementara kota itu sendiri terus berkembang dan bertambah penduduknya. Dalam hal ini tentu pemerintahan yang tidak berfungsi baik dalam melayani publik dan penuh tindak korupsi harus ditempatkan sebagai pendorong terjadinya kekerasan oleh karena kepercayaan publik pun menjadi amat minim terhadap pemerintah dan institusi-insitusi lainnya sehingga tidak aneh sering terjadi 
praktik main hakim sendiri. Orang kemudian lebih nyaman untuk melakukan sendiri proses penghakiman terhadap pelaku kejahatan misalnya, ketimbang menyerahkannya kepada institusi hukum yang ada.

Tentu, masih banyak faktor penyebab yang dapat ditambahkan di sini seperti misalnya dalam kasus konflik-konflik vertikal antara masyarakat dan pemerintah/negara. Namun yang perlu digarisbawahi adalah bahwa kemiskinan, ketimpangan, public service dan governance yang buruk seringkali adalah akibat dari kebijakankebijakan ekonomi yang serampangan yang bias pada pertumbuhan semata yang secara bersamaan cenderung menyepelekan mereka yang masih tertinggal dan miskin. Maka kebijakan-kebijakan ekonomi tersebut pun sebetulnya adalah juga bentuk dari kekerasan. Korupsi, kolusi, nepotisme tidak lain adalah bentuk dari kekerasan ekonomi. Ketika terjadi penggusuran di sana-sini dengan dalih pembangunan, maka di saat itulah telah terjadi pula kekerasan pembangunan. Tentu saja kekerasan ekonomi dan kekerasan pembangunan semacam ini amat bersangkut paut dengan kekerasan-kekerasan lainnya seperti kekerasan fisik, kekerasan hukum, kekerasan budaya dan sebagainya.

Bila demikian halnya, kiranya menyesatkan jika disebutkan bahwa yang gemar melakukan kekerasan adalah mereka yang miskin dan kurang terdidik. Lagi pula, untuk melakukan kekerasan dengan dampak yang luas dan menakutkan, membutuhkan kemampuan baik itu kekuasaan maupun uang yang justru tidak dimiliki oleh mereka yang miskin dan terbelakang.

Keputusasaan pada mereka yang miskin dan terbelakang itu bahkan sampai ada yang berujung pada tindak kekerasan terhadap dirinya sendiri, bahkan sampai mati dan bukannya membabi-buta mengamuk pada orang lain. Ada anak kecil yang mencoba bunuh diri lantaran uang sekolahnya belum dibayar sekian buian. Sementara kasus-kasus bunuh diri di Gunung Kidul, seperti disimpulkan Darmaningtyas, penyebabnya bukaniah mitos pulung gantung melainkan kondisi daerahnya yang gersang, tandus dan kemiskinan yang diderita masyarakatnya.

\section{Kekerasan Mengakibatkan Goncangan Jiwa}

Penelitian mutakhir tentang kajian trauma (trauma studies) mulai memahami bahwa trauma bukan semata-mata gejala kejiwaan yang bersifat individual. Trauma muncul sebagai akibat dari saling keterkaitan antara ingatan sosial dan ingatan pribadi tentang peristiwa yang mengguncang eksistensi kejiwaan. Dalam konteks Aceh, kompleksitas sosial dan kultural ini sangat penting mengingat bahwa masyarakat Aceh telah mengalami dan menjadi saksi berbagai macam kekerasan sejak berlangsungnya operasi keamanan di daerah ini. Oleh karena itu, pemahaman tentang trauma sebagai proses sosial dan sekaligus proses kejiwaan yang bersifat personal mutlak diperlukan untuk mencari jalan keluar dari lingkaran ingatan traumatis yang dialami oleh banyak orang Aceh.

Dengan kata lain, untuk memahami kompleksitas trauma di Aceh-dan di beberapa daerah yang pernah dilanda konflik dan bencana besar-diperlukan juga keterlibatan antropolog dan sosiolog yang memahami soal trauma di samping tentunya para pakar psikologi dan psikiatri. Kajian mutakhir trauma ini menekankan perlunya pendekatan'lintas disiplin. 
Meskipun agak sulit, dan barangkali tak pantas, membaṇdingkan antara satu bencana kemanusiaan dan bencana lainnya, situasi di Aceh ini barangkali dapat disejajarkan dengan peristiwa Holocaust saat jutaan kaum Yahudi dibantai oleh rezim Nazi Jerman. Holocaust juga meninggalkan persoalan trauma yang berdampak sangat lama. Pada tahun 1980-an, saat para psikiater dari Yale melakukan pengumpulan testimoni dari para survivor Holocaust, sebagian dari survivor ini masih memperiihatkan gejala trauma yang terekam secara mengesankan dalam film dokumenter Shoah yang dibuat oleh Claude Lanzmann.

Kajian tentang Holocaust ini langsung menjungkirbalikkan pandangan klasik-sering dipakai dalam kajian Post Traumatic Stress Disorder-bahwa trauma memiliki rentang waktu tertentu. Menariknya, Sigmund Freud sendiri pernah mengemukakan bahwa trauma adalah suatu ingatan yang direpresi. Dan, karena direpresi itulah maka trauma sering berlangsung secara tidak sadar dalam periode yang cukup lama. Guncangan psikologis yang disebabkan oleh ingatan mengerikan tentang gelombang tsunami, tentang mayat-mayat yang berserakan, dan tentang kehilangan banyak anggota keluarga sekaligus berpotensi untuk membentuk ingatan yang traumatis.(Fadjar I Thufail, 2005)

Situasi sosial yang pernah dialami masyarakat Aceh membuat persoalan trauma menjadi sangat kompleks sehingga harus disikapi secara sangat hati- hati. Ingatan tentang korban tsunami bercampur aduk dengan ingatan tentang korban kekerasan perang di Aceh, membentuk beberapa lapisan trauma yang saling menutupi. Selain itu, pemyataan yang selalu disampaikan oleh pihak GAM maupun pemerintah bahwa Aceh berada dalam keadaan "darurat" ikut membentuk kesadaran traumatis di kalangan masyarakat Aceh bahwa kekerasan selaiu mengancam mereka.

Sebagai sebuah konteks, pengalaman sejarah kekerasan di Aceh harus dipertimbangkan dan tak boleh dilupakan sebagai salah satu faktor pembentuk trauma. Oleh karena itu, pemahaman dan penanganan pascabencana tsunami harus memperhitungkan pengaruh-pengaruh sosial yảng mungkin memperburuk situasi traumatis masyarakat Aceh. Penghapusan keadaan "darurat" adalah saiah satu di antaranya, dan kesadaran dari pihak GAM juga diperlukan untuk menghentikan tekanan-tekanan terhadap masyarakat sipil Aceh.

Kajian trauma juga menggarisbawahi proses yang dalam studi psikologi sering disebut sebagai transference. Istilah ini merujuk pada "transfer" pengalaman traumatis yang terjadi dari orang yang secara fisik langsung mengalami peristiwa yang mengerikan kepada orang lain yang tak secara langsung mengalaminya. Freud memberi contoh bahwa psikoanalis juga dapat mengalami proses transference saat ia secara tak sadar melakukan identifikasi dengan korban trauma tersebut. Dori Laub, psikiater yang terlibat dalam pembuatan Shoah, me-ngatakan bahwa transference itu bisa terjadi saat psikoanalis, atau siapa pun juga yang melakukan wawancara dengan korban, "melihat" peristiwa yang mengerikan itu melalui narasi yang diceritakan oleh korban.

Relawan kemanusiaan yang terjun ke Aceh dan melihat mayat-mayat secara langsung atau ikut menangani korban-korban yang selamat juga rentan terhadap trauma. Memang agak disayangkan bahwa relawan kemanusiaan di indonesia jarang, atau bahkan hampir tak pernah, mendapat 
pelatihan khusus untuk menghadapi situasi yang sangat traumatis. Keterlibatan mereka kebanyakan didorong oleh rasa kemanusiaan yang dalam, tetapi tanpa menyadari bahwa benturan langsung dengan peristiwa yang mengerikan juga dapat berdampak pada situasi kejiwaan mereka. Relawan-relawan ini berisiko mengalami transference, dan bila tak diantisipasi atau ditangani secara tepat, akan menjadi bagian dari masyarakat yang mengalami trauma. Pemikiran jangka panjang dan menyeluruh untuk menangani situasi pascatsunami harus juga memasukkan faktor secondary trauma semacam ini.

Seperti dikemukakan di atas, trauma bukan semata-mata persoalan kejiwaan individúal. Struktur sosial, kekuasaan politik, dan nilai kebudayaan juga merupakan faktorfaktor yang memperfama trauma, tetapi juga dapat dipakai sebagai konteks untuk penyelesaian trauma. Oleh karena itu, trauma tak dapat hanya ditangani oleh psikolog dan psikiater-mereka yang lebih pandai menganalisis situasi kejiwaan individual- tetapi juga harus melibatkan antropolog dan sosiolog yang dapat mengidentifikasi faktor- faktor sosial, kultural, dan politik yang memperumit atau mempermudah penyelesaian ingatan traumatis individu maupun kolektif. Trauma pada dasarnya adalah ingatan peristiwa masa lalu yang mengerikan yang ditampakkan dalam, dan direpresi oleh, mediasi kultural dan sosial.

Seperti halnya peristiwa Holocaust, bencana alam di Aceh dapat mencetak ingatan traumatis yaing berlangsung sangat lama. Pengalaman masa lầ Aceh, telah menjadikan masyarakat Aceh rentan terhadap pengaruh trauma yang sangat kompleks. Pengelolaan pascabencana alam:tsunami tak boleh melupakan bahwa orang Aceh bukanlah masyarakat yang tak pernah tersentuh oleh peristiwa traumatis kolektif.

Terapi psikologis harus peka pada kenyataan bahwa kehilangan (loss) bagi masyarakat Aceh bukan semata-mata disebabkan oleh bencana alam tsunami, tetapi juga oleh konflik bersenjata yang berkepanjangan. Salah satu "terapi" yang mungkin dilakukan adalah membiarkan orang-orang Aceh untuk mencari kedamaian dengan masa lalu mereka yang penuh kekerasan.

\section{Penutup}

Dengan demikian, bila mentaati makna Pers Pancasila,makâ'Pers tidak-lagi asal muat, asal tayang tanpa mengindahkan dampaknya kepada masyarakat. Karena industri Pers berbeda dengan bisnis yang lain. Menjual, tetapi musti juga:mengingat pertanggungjawaban sosial kepada publik.Seperti dalam konsep yang di jalankan di SKH Kedaulatan Rakyat, pers bisa migunani tumraping liyan atau berguna untuk masyarakat.

\section{Daftar Pustaka}

Asshiddiqie, Jimly, 1996, Pergumulan Politik Pemerintah dan Parlemen dalam Sejarah, Telaah Perbandingan Konstitusi Berbagai Negara, Cet.l, Jakarta: UI Press.

Bagir Manan. 2001. Menyongsong Fajar Otonomi Daerah. Yogyakarta: Pusat Studi Hukum Fakultas Hukum UII.

Diantha, I.Md.Pasek, 1990. Tiga Tipe Pokok Sistem Pemerintahan dalam Demokrasi Moderen, Cet. I. Bandung: Abardin CV, Bandung. 
Topik: Budaya Kekerasan

Lijphart, Arend. 1995. Sistem Pemerintahan Parlementer dan Presidensial, Judul asli Partementary versus Presidential Government, disadur oleh Ibrahim $R$ dkk, Edisi I, Cetakan 1, Jakarta: PT Raja Grafindo Persada.

Masoed, Mochtar. 1989. Ekonomi dan Struktur Politik Orde Baru. Jakarta: LP3ES.

Mahfud, Mohammad, MD. "Pergeseran Politik Hukum Otonomi Daerah", Makalah Seminar Nasional Pergeseran Otonomi Daerah dan Demokratisasi di Indonesia, Kerjasama Fakultas Hukum UII dengan PERSAHI Jakarta, Yogyakarta, 5 Februari 1995.

Matutu, H. Mustamin DG, H. Abdul Latief, dan Hj. Hikmawati Mustamin, 2004,
Mandat, Delegasi, Attribusi dan Implementasinya di Indonesia", Yogyakarta: UII Press.

MTI (Masyarakat Transparansi Indonesia), tanpa tahun, Pembatasan Kekuasaan Presiden RI: Kajian Terhadap Mekanisme Pelaksanaan Kekuasaan Presiden RI dalam Hukum Positif Indonesia".

Sinaga, Patuan, 2004, "Hubungan Antara Kekuasaan Dengan Pouvoir Discretionnaire Dalam Penyelengggaraan Pemerintahan", dalam SF Marbun (ed.), 2004, Dimensi-dimensi Pemikiran Hukum Administrasi Negara, Yogyakarta: UII Press.

Sunggono, Bambang, 1994, Hukum dan Kebijaksanaan Publik, Jakarta: Sinar Grafika.

\section{$\square \square \square$}

